\title{
Interface modification for organic and perovskite solar cells
}

\author{
Chunhua Wang ${ }^{1,2}$ and Junliang Yang ${ }^{1,2^{*}}$
}

\begin{abstract}
Organic solar cells (OSCs) continuously attract much attention due to their potentials as the low-cost and lightweight sources of renewable energy, and the power conversion efficiency (PCE) of the state-of-the-art OSCs has reached over $10.0 \%$. Especially, there has been an unexpected breakthrough and rapid evolution of highly efficient organic-inorganic hybrid perovskite solar cells (PSCs), and the PCE has been improved to over $20 \%$. The interface plays a very important role on the performance of both OSCs and PSCs, as well as their stability. It is imperative to control the interface properties and understand the mechanisms for obtaining highly efficient OSCs and PSCs. In this review, we will summarize our research progress on the interface modification of OSCs and PSCs using the electron transport layer and hole transport layer, as well as the molecular template layer.
\end{abstract}

Keywords: organic solar cells, perovskite solar cells, interface, bulk heterojunction, planar heterojunction.

\section{INTRODUCTION}

Solar cells acting as one of the most promising renewable energy candidates will meet the growing requirements for the energy sources, which is facing the dwindling of fossil energy and the aggravation of environmental pollution [1-3]. It is very important to improve the power conversion efficiency $(P C E)$ and reduce the cost for greatly accelerating the commercialization of solar cells. Organic solar cells (OSCs) and organic-inorganic hybrid perovskite solar cells (PSCs), as the third-generation solar cells, are attracting much attention due to their potentials as the low-cost, flexible and lightweight sources of renewable energy, as well as matching with high-output, large-scale roll-to-roll (R2R) printing techniques [4-8]. The PCEs of the state-of-the-art OSCs has reached over $10.0 \%$, resulting from the progress in new materials, device engineering, device physics, etc. [9-11]. Especially, there has been an unexpected breakthrough and rapid evolution of highly efficient PSCs, and the PCE has been improved to over 20\% [12-14].

However, there are still many issues that restrict the commercialization of OSCs and PSCs from lab-scale to largearea fabrication. The interface is of great importance to the PCEs and stability of both OSCs and PSCs, and there are lots of studies focused on the interface materials as well as their influence on the performance [15-21]. The active layer in OSCs would be oxidized and the degradation of devices would be accelerated as exposed to ambient environment, which could be attributed to the interfaces between the active layer and the electrodes $[15,16]$. While in PSCs, the interface decay can easily occur even when the devices are exposed in air for a short time since the perovskite materials are sensitive to moisture [17,22-24]. As the interface materials inserted into solar cell devices, the degradation rate could be greatly decreased.

We have done a lot of work on the growth of ordered organic semiconductor thin film and the control of interface morphology, as well as their applications in organic optoelectronic devices, which are summarized in the reviews [25-27]. Focusing on the interface issues of OSCs and PSCs, our group has been carrying out the research, and some interesting results have been obtained [28-43]. We are hopeful to achieve two aims through the interface study. One is that the stable OSCs and PSCs with high PCEs can be fabricated by interface engineering. The other is that the thickness-independent interface layer can be processed by large-scale printing techniques for large-area, highly efficient OSCs and PSCs. Herein, this review will summarize recent research progress on OSCs and PSCs using interface

${ }^{1}$ State Key Laboratory of Powder Metallurgy, Central South University, Changsha 410083, China

${ }^{2}$ Hunan Key Laboratory for Super-microstructure and Ultrafast Process, School of Physics and Electronics, Central South University, Changsha 410083, China

* Corresponding author (email: junliang.yang@csu.edu.cn) 
modification in our group, which would hopefully accelerate the development of OSCs and PSCs, as well as their commercialization.

\section{INTERFACE MODIFICATION FOR OSCs}

\section{Structure of OSCs}

The OSCs can be divided into small molecular solar cells and polymer solar cells. The former is normally fabricated by vacuum deposition, while the latter is normally fabricated by solution process which can match with large-scale $\mathrm{R} 2 \mathrm{R}$ printing techniques $[5,6,44,45]$. The typical structures of OSCs are shown in Fig. 1, which includes conventional forward structure and inverted structure. They are composed of anode, hole transport layer (HTL), active layer, electron transport layer (ETL) and cathode. The active layer has two parts-electron donor and electron acceptor, which form the planar heterojunction or bulk heterojunction. In OSCs, the heterojunction active layer first absorbs photons and generates tightly bound electron-hole pairs (excitons) in both donor and acceptor parts, then the excitons diffuse to the donor-acceptor interface and dissociate into electrons and holes, finally the charges transport and are collected at the anode (holes) and cathode (electrons) [26]. The HTL and ETL, as the interface layers, can improve the interface electronic structure and interface contact between the active layer and electrodes, which dramatically enhance the charge extraction and transport. Thus it would result in great improvement in device performance parameters, including open-circuit voltage $\left(V_{o c}\right)$, short-circuit current $\left(J_{\text {sc }}\right)$, fill factor $(F F)$ and $P C E$, as well as the stability [46-48].

\section{Interface modification for small molecular solar cells using molecular template layer}

Thin film morphology and molecular orientation are very important to the charge transport and device performance, and molecular template growth has been developed to fabricate high-quality organic semiconductor thin film with controllable morphology and molecular orientation $[25,27,28,34]$. In order to form ordered bulk heterojunction instead of planar heterojunction, the combination of
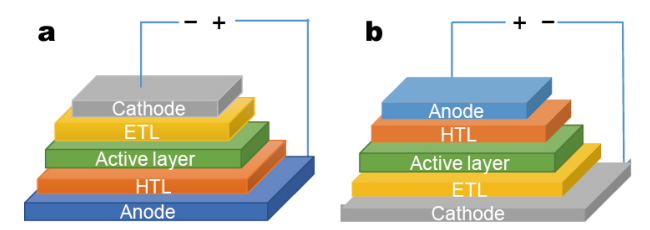

Figure 1 Schematic of (a) conventional forward and (b) inverted structural organic solar cells. molecular template growth and glancing angle deposition technique was used to fabricate ordered nanocolumn-array phthalocynine organic semiconductor thin film with controllable molecular orientation, in which a controllable lying-down molecular orientation was obtained in the models of planar molecule copper phthalocynine $(\mathrm{CuPc})$ and non-planar molecule chloroaluminum phthalocyanine (AlClPc) [28], as shown in Fig. 2. The planar perylene-3, 4, 9, 10-tetracarboxylic-3, 4, 9, 10-dianhydride (PTCDA) molecular template layer induces phthalocynine molecules arrange with a lying-down molecular orientation, in which the $\pi-\pi$ stacking is vertical to the substrate, improving the charge transport along the vertical direction; While the GLAD technique supports the formation of nanocolumn-array thin films, supplying a much larger exposed surface area than the conventional compact thin films.

Because of the mismatch of energy levels between the template layer PTCDA, the electrode and the active layer, the $V_{\text {oc }}$ normally decreases obviously although the $J_{s c}$ increases for PTCDA-templated small molecular solar cells [49]. Thus molybdenum oxide $\left(\mathrm{MoO}_{x}\right)$ can be inserted to tune the energy levels between the electrode and the active layer. The combination of $\mathrm{MoO}_{x}$ and molecular template layer PTCDA as the interface modification layers in small molecular solar cells results in the obvious improvement for both $V_{\text {oc }}$ and $J_{\text {sc }}$, as well as the great enhancement in PCEs [34,49], as summarized in Table 1. The insertion of a $\mathrm{MoO}_{x}$ layer as the HTL can lead to the improvement of the $V_{\text {oc }}$ due to the large difference in work function between the $\mathrm{MoO}_{x}$ and the active layer materials, which would cause significant band-bending and enhance the built-in field. Meanwhile, the $\mathrm{MoO}_{x}$ layer can also pin the highest occupied molecular orbital (HOMO) levels of the adjacent organic layer materials to defect states (oxygen vacancies) in the near Fermi level of the n-type $\mathrm{MoO}_{x}$ interlayer, which is helpful to improve the hole extraction [49].

\section{Interface modification for polymer OSCs employing $\mathrm{TiO}_{2}$ nanoparticles (NPs) and graphene oxide (GO)}

\section{Conventional forward structural polymer OSCs by employing $\mathrm{TiO}_{2} \mathrm{NPs}$}

Titanium oxide $\left(\mathrm{TiO}_{x}\right)$ has been used in polymer solar cells which can act as optical spacer, ETL or hole blocking layer (HBL), as well as shielding and scavenging layer [50-53]. It obviously enhances the performance of polymer solar cells and prevents the permeation of moisture and oxygen into the active layer. However, $\mathrm{TiO}_{x}$ is thermally unstable in post-annealing processes at the temperature over $80^{\circ} \mathrm{C}$ 
$\mathbf{a}$

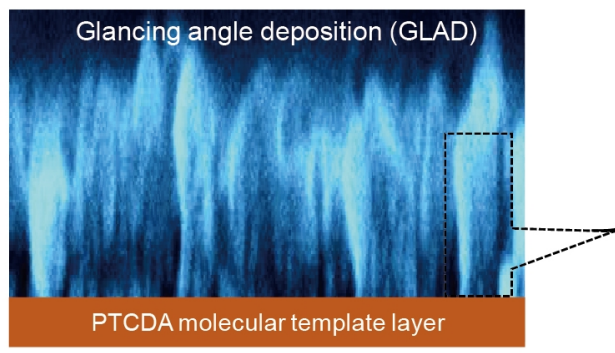

b

CuPc

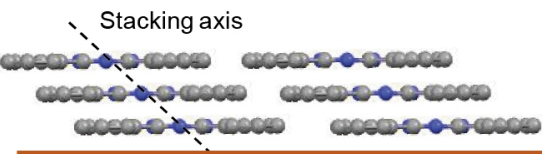

PTCDA molecular template layer

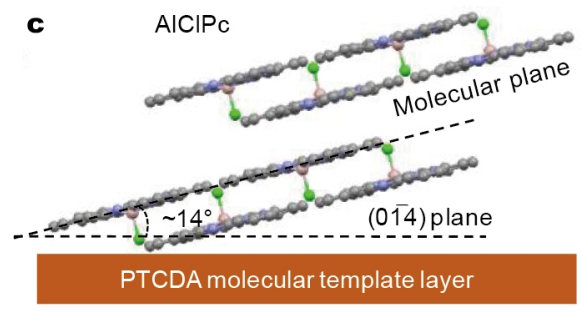

Figure 2 Schematics of $\mathrm{CuPc}$ and AlClPc molecular arrangement in nanocolumn-array thin films fabricated by combining PTCDA template growth and GLAD techniques. Reprinted with permission from [28], Copyright 2013, Elsevier.

Table 1 Performance parameters of OSCs with and without interface layer modification

\begin{tabular}{|c|c|c|c|c|c|}
\hline OSCs structure & $V_{\mathrm{oc}}(\mathrm{V})$ & $J_{\mathrm{sc}}\left(\mathrm{mA} \mathrm{cm}^{-2}\right)$ & $F F(\%)$ & PCE (\%) & Ref. \\
\hline ITO/ClAlPc/C $60 / \mathrm{BCP} / \mathrm{Al}$ & 0.59 & 5.33 & 58 & 1.80 & \multirow[t]{4}{*}{ [49] } \\
\hline ITO/PTCDA/ClAlPc/C $60 / \mathrm{BCP} / \mathrm{Al}$ & 0.46 & 6.13 & 50 & 1.40 & \\
\hline $\mathrm{ITO} / \mathrm{MoO}_{x} / \mathrm{C}_{60} / \mathrm{BCP} / \mathrm{Al}$ & 0.81 & 5.30 & 58 & 2.60 & \\
\hline $\mathrm{ITO} / \mathrm{MoO}_{x} / \mathrm{PTCDA} / \mathrm{ClAlPc} / \mathrm{C}_{60} / \mathrm{BCP} / \mathrm{Al}$ & 0.79 & 6.53 & 58 & 3.00 & \\
\hline $\mathrm{ITO} / \mathrm{CuPc} / \mathrm{C}_{60} / \mathrm{Alq}_{3} / \mathrm{Al}$ & 0.39 & 3.54 & 55.1 & 0.76 & \multirow[t]{6}{*}{ [34] } \\
\hline $\mathrm{ITO} / \mathrm{MoO}_{x} / \mathrm{CuPc} / \mathrm{C}_{60} / \mathrm{Alq}_{3} / \mathrm{Al}$ & 0.56 & 3.76 & 50.0 & 1.05 & \\
\hline $\mathrm{ITO} / \mathrm{MoO}_{x} / \mathrm{PTCDA} / \mathrm{CuPc} / \mathrm{C}_{60} / \mathrm{Alq}_{3} / \mathrm{Al}$ & 0.53 & 5.13 & 54.2 & 1.48 & \\
\hline $\mathrm{ITO} / \mathrm{CuPc} / \mathrm{PCBM} / \mathrm{Alq}_{3} / \mathrm{Al}$ & 0.44 & 3.16 & 52.5 & 0.73 & \\
\hline $\mathrm{ITO} / \mathrm{MoO}_{x} / \mathrm{CuPc} / \mathrm{PCBM} / \mathrm{Alq}_{3} / \mathrm{Al}$ & 0.61 & 3.15 & 54.7 & 1.05 & \\
\hline $\mathrm{ITO} / \mathrm{MoO}_{x} / \mathrm{PTCDA} / \mathrm{CuPc} / \mathrm{PCBM} / \mathrm{Alq}_{3} / \mathrm{Al}$ & 0.60 & 4.29 & 55.6 & 1.44 & \\
\hline ITO/PEDOT:PSS/P3HT:PCBM/Al & 0.59 & 9.79 & 53 & 3.09 & \multirow[t]{4}{*}{ [29] } \\
\hline ITO/PEDOT:PSS/P3HT:PCBM/O3- $\mathrm{TiO}_{2} / \mathrm{Al}$ & 0.52 & 9.58 & 60 & 3.04 & \\
\hline ITO/PEDOT:PSS/P3HT:PCBM/O7- $\mathrm{TiO}_{2} / \mathrm{Al}$ & 0.58 & 12.69 & 58 & 4.24 & \\
\hline ITO/PEDOT:PSS/P3HT:PCBM/H7- $\mathrm{TiO}_{2} / \mathrm{Al}$ & 0.57 & 12.83 & 56 & 4.12 & \\
\hline ITO/H7-TiO $/ 2$ P3HT:PCBM/PEDOT:PSS/Al & 0.60 & 11.84 & 63 & 4.42 & {$[30]$} \\
\hline ITO/PEDOT:PSS/PBDTPO-DTBO:PC ${ }_{71} \mathrm{BM} / \mathrm{Al}$ & 0.82 & 10.92 & 48 & 4.39 & \multirow{2}{*}{ [33] } \\
\hline ITO/PEDOT:PSS/PBDTPO-DTBO:PC ${ }_{71} \mathrm{BM} / \mathrm{H} 7-\mathrm{TiO}_{2} / \mathrm{Al}$ & 0.79 & 12.23 & 51 & 5.03 & \\
\hline ITO/PEDOT:PSS/TIBT:PCBM/Al & 0.89 & 5.76 & 55 & 2.82 & \multirow[t]{2}{*}{ [33] } \\
\hline ITO/PEDOT:PSS/TIBDT:PCBM/ $\mathrm{H} 7-\mathrm{TiO}_{2} / \mathrm{Al}$ & 0.91 & 7.96 & 50 & 3.58 & \\
\hline ITO/GO (0.1 mg mL $\left.{ }^{-1}\right) / \mathrm{P} 3 \mathrm{HT}: \mathrm{PCBM} / \mathrm{Al}$ & 0.23 & 7.20 & 29.8 & 0.50 & \multirow[t]{6}{*}{32} \\
\hline ITO/GO $\left(0.3 \mathrm{mg} \mathrm{mL}^{-1}\right) / \mathrm{P} 3 \mathrm{HT}: \mathrm{PCBM} / \mathrm{Al}$ & 0.42 & 7.47 & 34.1 & 1.08 & \\
\hline ITO/GO $\left(0.5 \mathrm{mg} \mathrm{mL}^{-1}\right) / \mathrm{P} 3 \mathrm{HT}: \mathrm{PCBM} / \mathrm{Al}$ & 0.51 & 8.14 & 43.2 & 1.82 & \\
\hline ITO/GO (1.0 mg mL $\left.{ }^{-1}\right) / \mathrm{P} 3 \mathrm{HT}: \mathrm{PCBM} / \mathrm{Al}$ & 0.55 & 10.19 & 54.8 & 3.09 & \\
\hline ITO/GO $\left(2.0 \mathrm{mg} \mathrm{mL}^{-1}\right) / \mathrm{P} 3 \mathrm{HT}: \mathrm{PCBM} / \mathrm{Al}$ & 0.52 & 10.48 & 53.8 & 2.91 & \\
\hline ITO/GO $\left(1.0 \mathrm{mg} \mathrm{mL}^{-1}\right) / \mathrm{P} 3 \mathrm{HT}: \mathrm{PCBM} / \mathrm{TiO}_{2} / \mathrm{Al}$ & 0.57 & 10.41 & 54.9 & 3.32 & \\
\hline
\end{tabular}


[18]. Furthermore, it involves a sol-gel synthesis and subsequently a hydrolysis in air after the deposition, risking the degradation of polymer solar cells with a conventional forward structure. Thus, $\mathrm{TiO}_{2}$ nanoparticles (NPs) was developed to be a proper candidate to replace $\mathrm{TiO}_{x}$ because of its thermally stability and the role as efficient ETL or HBL $[54,55]$.

In order to overcome conventional complex procedures and the drawbacks of a high-temperature hydrolytic process and universal low carrier mobility, we developed newly solution-based method to synthesize high-quality $\mathrm{TiO}_{2}$ NPs [29]. Based on the solvent types, three kinds of $\mathrm{TiO}_{2} \mathrm{NPs}$, i.e., O3- $\mathrm{TiO}_{2}, \mathrm{O} 7-\mathrm{TiO}_{2}$ and $\mathrm{H} 7-\mathrm{TiO}_{2}$, can be synthesized, respectively (Fig. 3). The transmission electron microscopy (TEM) images, selected area electron diffraction (SAED) and X-ray diffraction (XRD) results suggested that $\mathrm{O} 3-\mathrm{TiO}_{2}$ NPs were amorphous and composed of sphere-like morphology with the size of about $2.5 \mathrm{~nm}$. The $\mathrm{O} 7-\mathrm{TiO}_{2} \mathrm{NPs}$ were weakly crystallized and oval-like morphology with the size of about $3.6 \mathrm{~nm}$. While the $\mathrm{H} 7-\mathrm{TiO}_{2}$ NPs were highly crystallized with the enlarged size to about $5.5 \mathrm{~nm}$. The results suggested that the appropriate excessive $\mathrm{H}_{2} \mathrm{O}$ for the process of peptization was beneficial to improve the growth and crystallinity. The $\mathrm{TiO}_{2} \mathrm{NPs}$ referred below is $\mathrm{H} 7-\mathrm{TiO}_{2} \mathrm{NPs}$ if without special illustration.

These three kinds of $\mathrm{TiO}_{2}$ NPs were used to fabricate polymer solar cells based on the bulk heterojunction of P3HT:PCBM with a structure of ITO/PEDOT:PSS/ $\mathrm{P} 3 \mathrm{HT}: \mathrm{PCBM} / \mathrm{TiO}_{2} / \mathrm{Al}$, and the performance parameters are summarized in Table 1 [29]. As compared with the reference device without $\mathrm{TiO}_{2}$ NPs layer, polymer solar

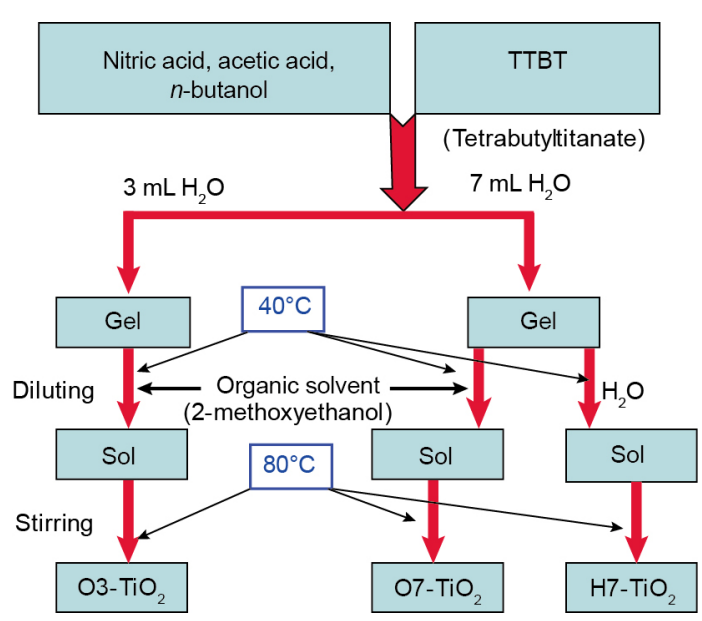

Figure 3 Schematic of synthesis routs for three types of $\mathrm{TiO}_{2} \mathrm{NPs}$. Modified from [29], Copyright 2014, Elsevier. cells with $\mathrm{O} 3-\mathrm{TiO}_{2} \mathrm{NPs}$ showed the similar performance parameters, while the performance parameters of $\mathrm{O} 7-\mathrm{TiO}_{2}$ and $\mathrm{H} 7-\mathrm{TiO}_{2}$ NPs-based polymer solar cells showed great improvement. The PCEs were improved from about $3.09 \%$ (reference device) to $4.24 \%$ and $4.12 \%$, respectively, resulting from the large improvement in the $J_{s c}$ which was enhanced from 9.79 (reference device) to 12.69 and $12.83 \mathrm{~mA} \mathrm{~cm}^{-2}$, respectively. The ultraviolet photoelectron spectrometer (UPS) measurement suggested that the work function of $\mathrm{O}_{3}-\mathrm{TiO}_{2} \mathrm{NPs}, \mathrm{O} 7-\mathrm{TiO}_{2} \mathrm{NPs}$ and $\mathrm{H} 7-\mathrm{TiO}_{2} \mathrm{NPs}$ were 3.9, 4.4 and $4.5 \mathrm{eV}$, respectively. The positions of work function of the $\mathrm{O} 7-\mathrm{TiO}_{2} \mathrm{NPs}$ and $\mathrm{H} 7-\mathrm{TiO}_{2} \mathrm{NPs}$ are helpful to the transfer of the electrons from the PCBM to the cathode (Al). Furthermore, the carrier mobility of crystallized $\mathrm{TiO}_{2}$ NPs would be much better than that of amorphous $\mathrm{TiO}_{2}$ NPs. Meanwhile, the absorption of polymer OSCs in reflection geometry could be enhanced with $\mathrm{TiO}_{2} \mathrm{NPs}$ layer because it worked as the optical spacer in polymer OSCs devices. These reasons are all advantageous to the improvement of $J_{\mathrm{sc}}$.

Furthermore, these $\mathrm{TiO}_{2} \mathrm{NPs}$ sols are very stable and can be stored stably at least one year in atmospheric environment without any precipitation. The P3HT:PCBM solar cells with $\mathrm{H} 7-\mathrm{TiO}_{2}$ NPs layer prepared from initial $\mathrm{TiO}_{2}$ NPs sol and the $\mathrm{TiO}_{2}$ NPs sol stored in air for 1 year exhibited the similar performance parameters [33]. More interestingly, these $\mathrm{TiO}_{2} \mathrm{NPs}$ layer does not require thermal annealing and showed the similar properties to that treated with thermal annealing. For example, XRD results showed in Fig. 4 suggested that the $\mathrm{TiO}_{2}$ NPs layers without thermal annealing and with thermal annealing at $150^{\circ} \mathrm{C}$ had the comparable diffraction peaks, implying that the $\mathrm{TiO}_{2} \mathrm{NPs}$ were already crystallized in sols. These solution-processed, annealing-free $\mathrm{TiO}_{2} \mathrm{NPs}$ were used as ETL in P3HT:PCBM solar cells and showed improved performance parameters [33]. Meanwhile, it can also be used as ETL in low band gap alkoxylphenyl substituted [1,2-b:4,5-b'] dithiophene (PBDTPO-DTBO) polymer solar cells and soluble small molecule benzodithiophene derivative (TIBDT) solar cells with improved performance, as shown in Table 1. These solution-processed, annealing-free $\mathrm{TiO}_{2} \mathrm{NPs}$ can match with printed techniques and show great potential application in printed solar cells and other optoelectronic devices.

In addition, $\mathrm{TiO}_{2} \mathrm{NPs}$ can improve the air-stability of polymer OSCs. As shown in Fig. 5a, the normalized PCEs for polymer OSCs with and without $\mathrm{TiO}_{2} \mathrm{NPs}$ exposed in the air for $200 \mathrm{~h}$ were tested. Polymer OSCs with $\mathrm{TiO}_{2} \mathrm{NPs}$ layer showed much better air-stability than that without $\mathrm{TiO}_{2}$ NPs layer. After $200 \mathrm{~h}$, the PCEs of reference OSCs 


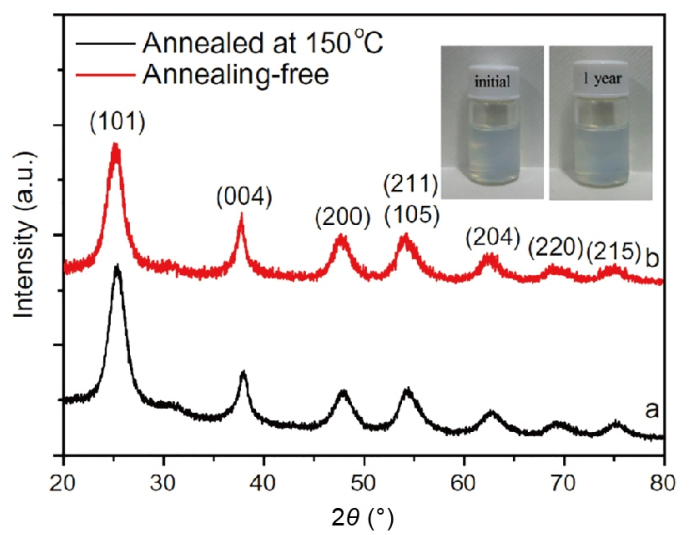

Figure 4 XRD patterns of $\mathrm{TiO}_{2} \mathrm{NPs}$ with thermal annealing at $150^{\circ} \mathrm{C}$ (curve a) and without thermal annealing (curve b). Inset is the photo of $\mathrm{TiO}_{2}$ NPs sols initially synthesized and stored for 1 year in air, respectively. Reprinted with permission from [33], Copyright 2015, Elsevier.
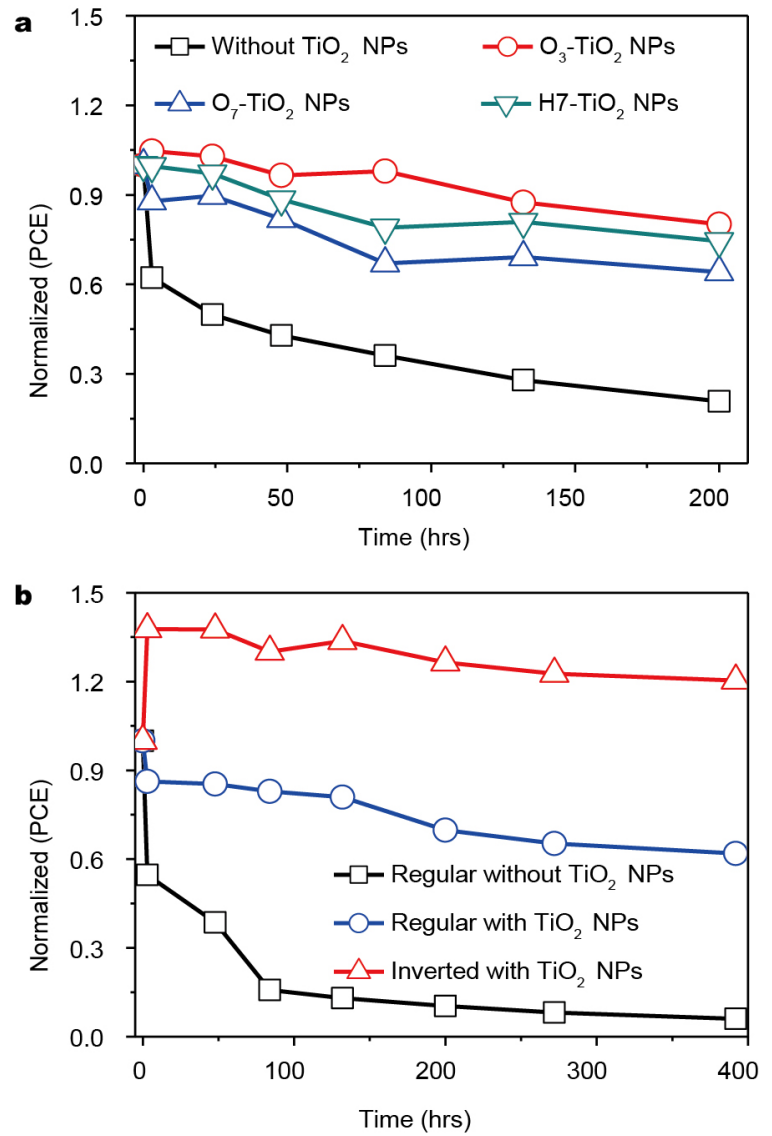

Figure 5 (a) The degradation of normalized PCEs for OSCs with and without $\mathrm{TiO}_{2}$ NPs. Reprinted with permission from [29], Copyright 2014, Elsevier. (b) The degradation of normalized PCEs for conventional forward OSCs without $\mathrm{TiO}_{2} \mathrm{NPs}$, conventional forward OSCs with $\mathrm{TiO}_{2} \mathrm{NPs}$, and inverted OSCs with $\mathrm{TiO}_{2} \mathrm{NPs}$, respectively. Reprinted with permission from [30], Copyright 2014, Elsevier. dropped to about $29 \%$ of initial value, while the PCEs of the OSCs with $\mathrm{O} 3-\mathrm{TiO}_{2}, \mathrm{O} 7-\mathrm{TiO}_{2}$ and $\mathrm{H} 7-\mathrm{TiO}_{2} \mathrm{TiO}_{2} \mathrm{NPs}$ layer dropped to about $80 \%, 64 \%$ and $75 \%$ of their initial values, respectively. The main reason of degradation came from the decline of the $J_{\mathrm{sc}}$. Normally the typical decay curve includes two stages, i.e., the initial decay resulting from interfacial degradation and the longer time scale decay resulting from the intrinsic or oxidation driven degradation of the bulk active layers. At the first $3 \mathrm{~h}$ exposed in air, the reference device showed linearly drops to about $60 \%$ of the initial value. However, the degradation phenomenon was distinctly eliminated in OSCs with $\mathrm{TiO}_{2} \mathrm{NPs}$ layer. The results indicated that $\mathrm{TiO}_{2} \mathrm{NPs}$ layer played an important role to improve organic/electrode interface and prevent the interfacial degradation efficiently. At a longer term, the degradation rate was slowed down as well for OSCs with $\mathrm{TiO}_{2}$ NPs, suggesting that $\mathrm{TiO}_{2} \mathrm{NPs}$ layer could act as a shielding and scavenging layer for preventing the intrusion of oxygen and humidity into the electronically active polymers.

Inverted structural polymer OSCs by employing $\mathrm{TiO}_{2} \mathrm{NPs}$ As compared with conventional forward structural OSCs, inverted structural OSCs have also attracted much attention due to the higher PCEs and better stability [56,57]. The $\mathrm{TiO}_{2} \mathrm{NPs}$ synthesized by the above low-temperature, solution-processed method can also be used as the ETL in inverted OSCs NPs. The performance parameters of the inverted OSCs based on P3HT:PCBM bulk heterojunction with a structure of $\mathrm{ITO} / \mathrm{TiO}_{2}$ NPs/ P3HT:PCBM/PEDOT:PSS/Ag were dramatically improved and the average PCE of $4.42 \%$ was achieved, which is better than that of conventional forward structural OSCs (Table 1) [30]. Mott-Schottky capacitance analysis proved that the inverted OSCs had a higher built-in potential and a less depletion width as compared with conventional structural OSCs, which supported the improvement of performance parameters.

Moreover, the inverted structural OSCs with $\mathrm{TiO}_{2} \mathrm{NPs}$ layer showed much better stability in air without encapsulation than conventional forward structural OSCs with or without $\mathrm{TiO}_{2} \mathrm{NPs}$ (Fig. 5b). Especially, the performance parameters of the inverted OSCs could be obviously improved due to the oxidization of Ag electrode [58]. Stored in ambient condition without encapsulation, the oxidized Ag electrode can form a layer of silver oxide. Accordingly, the work function of the Ag increases from 4.3 to $5.0 \mathrm{eV}$, resulting in an enhanced built-in potential and an improved $V_{\text {oc. }}$ Meanwhile, the Ag with a higher work function is advantageous to the formation of an Ohmic contact between 
the PEDOT:PSS layer and the electrode, which would induce the pinning of the energy level of the electrode towards the lowest unoccupied molecular orbital (LUMO) level of the donor, supporting the improvement in $V_{\mathrm{oc}}$ and $F F$. Thus, the PCEs showed an obvious increase at the first $24 \mathrm{~h}$, and then the inverted OSCs degrade at a very slow rate (Fig. 5b). The PCEs were about $87 \%$ of its original values even after $400 \mathrm{~h}$ exposure in air. While the PCEs of the conventional forward OSCs with $\mathrm{TiO}_{2} \mathrm{NPs}$ were just about $60 \%$ of its original values after $400 \mathrm{~h}$ exposure in air, and the PCEs of conventional forward OSCs without $\mathrm{TiO}_{2} \mathrm{NPs}$ were just about $10 \%$ of its original values after only $100 \mathrm{~h}$ exposure in air.

The results discussed above suggest that the synthesized $\mathrm{TiO}_{2}$ NPs by the low-temperature, solution-processed method can be used as the ETL in both conventional forward and inverted OSCs, of which the performance parameters and stability can be dramatically improved. Especially, these $\mathrm{TiO}_{2}$ NPs layer can be deposited with an annealing-free, solution process, which can match with printing techniques, showing great potential applications in printed large-area and flexible OCS, as well as in printed electronics.

\section{OSCs by employing GO layer}

The conducting polymer PEDOT:PSS has been widely used as an HTL for increasing the hole collection and improving the anode contact in OSCs. However, the PEDOT:PSS has the problems of hygroscopic properties, high acidity and inhomogeneous electrical properties, resulting in a poor long-term stability. Some inorganic HTL materials were used to replace the PEDOT:PSS for hopefully solving some of the problems, for example, $\mathrm{V}_{2} \mathrm{O}_{5}$, $\mathrm{MoO}_{3}$. Especially, many efforts are being made to develop low-cost and solution-processable interfacial materials, which are compatible to R2R printing process, for highly efficient OSCs. The solution-processed GO is also an possibly efficient HTL instead of the PEDOT:PSS in OSCs $[59,60]$.

The performance parameters of OSCs with GO as the HTL are comparable to those using the PEDOT:PSS as the HTL, and a PCE of $3.09 \%$ could be obtained (Table 1) [32]. However, the thickness of GO layer greatly influences the $P C E s$, which is possible to be an obstacle for the deposition using low-cost, large-scale printing process. The PCEs could be further improved by using $\mathrm{TiO}_{2} \mathrm{NPs}$ layer as the ETL and reached to $3.32 \%$. The interface capacitance analysis and electrochemical impedance measurement confirmed that the GO as the HTL in PSCs had better interface properties than the PEDOT:PSS. Meanwhile, the stability of OSCs with a GO layer was much better than those with PEDOT:PSS layer. The PCEs of OSCs with both GO and $\mathrm{TiO}_{2}$ NPs layers could retain $60 \%$ of its initial value after $180 \mathrm{~h}$ exposure in high humidity atmospheric environment (air humidity $\sim 80 \%$ ). The combination of GO and $\mathrm{TiO}_{2}$ NPs acted as the HTL and ETL, respectively, has the potentials for preparing efficient and stable OSCs.

\section{INTERFACE MODIFICATION FOR PSCs}

\section{Structure of PSCs}

PSCs have attracted tremendous attention in solar cell field due to their superior properties such as small bandgap, long carrier diffusion length, high carrier mobility, and so on. It showed a booming development during the past years and the PCEs have been improved to be over 20\% [12-14]. There are normally two types of device architectures, mesoporous structure and planar heterojunction (PHJ) structure. In mesoporous structural PSCs, a mesoporous metal oxide scaffold, for example, $\mathrm{TiO}_{2}, \mathrm{Al}_{2} \mathrm{O}_{3}$, is deposited and treated with a high-temperature sintering process $\left(\sim 450^{\circ} \mathrm{C}\right)$ [61-63], which is a possible obstacle for fabricating PSCs on flexible substrate. Thus, the low-temperature, solution-processed $\mathrm{PHJ}$ structure is a good choice to fabricate large-area, flexible PSCs, which can be compatible with low-cost, large-scale R2R techniques [6,7].

The structure of PHJ-PSCs is very similar to OSCs, and it can also be divided into conventional forward structure and inverted structure (Fig. 6). Because PSCs were developed from dye-sensitized solar cells (DSSCs) [61], the conventional forward structure is defined as cathode/ETL/Perovskite/HTL/anode (Fig. 6a), and the inverted structure is accordingly defined as anode/HTL/Perovskite/HTL/cathode (Fig. 6b). Herein, the discussion is just focused on the inverted structural PSCs, which is a little similar to the conventional structure in OSCs. The perovskite layer, as an ambipolar transport layer, is the core part of the overall PSC device. Under the illumination, the excitons (electron-hole pairs) separate in the perovskite layer, and then the electron and hole migrate to ETL and HTL, respectively. Eventually they are collected by cathode and anode, respectively. The perovskite layer itself plays an important role in determining the device performance. The HTL and ETL, as the interface layers, have enormous effect on carrier extraction and transport due to the effective carrier extraction and separation occurring at the interfaces between perovskite and them. Thus, the performance of PSCs is determined by both perovskite film quality and their interfaces. 
$\mathbf{a}$

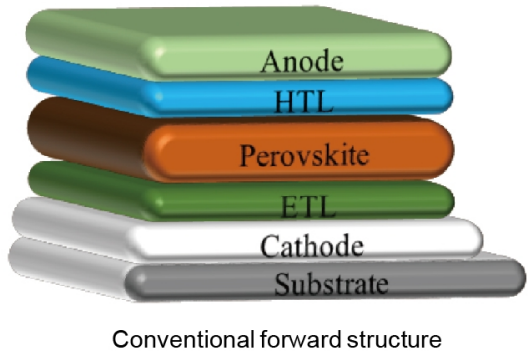

b

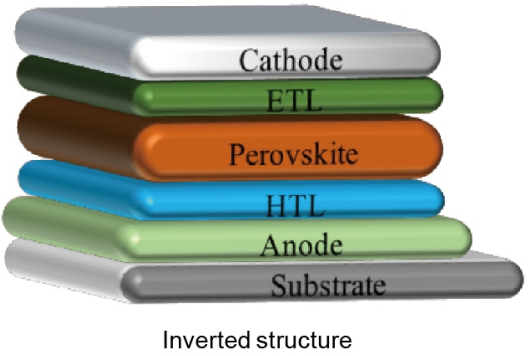

Figure 6 The schematic of (a) conventional forward structure and (b) inverted structure of PSCs.

\section{PHJ-PSCs with interface layers PEDOT:PSS and PCBM}

The PEDOT:PSS and PCBM are typical HTL and electronacceptor in OSCs, respectively. Since their introduction into PSCs [64,65], they have attracted great attention due to their low-temperature, solution process which matches with large-scale printing techniques. The simple PHJ-PSCs are structured with ITO/PEDOT:PSS/ $\mathrm{CH}_{3} \mathrm{NH}_{3} \mathrm{PbI}_{3} / \mathrm{PCBM} / \mathrm{Al}$. Based on the research on the fabrication parameters, high-quality $\mathrm{CH}_{3} \mathrm{NH}_{3} \mathrm{PbI}_{3}$ perovskite thin film can be fabricated using solvent engineering method with the optimized precursors $\mathrm{PbI}_{2}$ and $\mathrm{CH}_{3} \mathrm{NH}_{3} \mathrm{PbI}_{3}$ at a ratio of $1: 1$ [36]. The thickness of the PEDOT:PSS is about $40 \mathrm{~nm}$ which is similar to that in OSCs. However, the thickness of the PCBM ETL layer obviously influenced the performance parameters of PHJ-PSCs, and the average PCEs could be improved from $6.15 \%$ to $9.26 \%$ without optimizing the thickness of $\mathrm{CH}_{3} \mathrm{NH}_{3} \mathrm{PbI}_{3}$ layer (Table 2). The results suggested that a thick PCBM layer would increase the series resistance of PHJ-PSCs because of its low conductivity, while a very thin PCBM layer could not fully cover the perovskite layer and the top electrode would directly contact to perovskite layer. The thickness of PCBM layer was optimized to be about $30 \mathrm{~nm}$, and a relatively high average $P C E$ of $9.26 \%$ was achieved with a 210 nm perovskite layer. If reducing or increasing the thickness of PCBM layer, both $V_{\text {oc }}$ and $J_{\text {sc }}$ decreased, resulting in the lower PCEs. Further optimizing the thickness of perovskite layer, the average PCEs of $12.56 \%$ with a $J_{\text {sc }}$ of $19.99 \mathrm{~mA}$ $\mathrm{cm}^{-2}, V_{\text {oc }}$ of $0.99 \mathrm{~V}$ and $F F$ of $63 \%$ could be achieved, of which the best PCE was up to $13.49 \%$. More importantly, the PHJ-PSCs with this simple structure hardly showed any hysteresis regardless of different scanning directions and speeds.

\section{PHJ-PSCs modified with Au@SiO $\mathrm{SPs}_{2}$}

In order to maximize the $J_{\mathrm{sc}}$ and enhance the PCEs accordingly, one of effective and simple strategies is to increase the light absorption in the active layer at the optimized thickness. Metal NPs have been successfully used to moderately improve the performance of OSCs and DSSCs due to their excited localized surface plasmon (SP) resonance [66,67]. The photovoltaic performance parameters would be greatly influenced by the size, shape, component, and dielectric environment of the metal NPs. The solar cells with metal NPs enwrapped by insulated dielectric layer would produce better photovoltaic performance than that with bare metal NPs because the insulator layer could avoid the direct contact between metal NPs and the active layer which would

Table 2 Performance parameters of PHJ-PSCs with the interface layers at different thicknesses. The best PCEs are shown in brackets.

\begin{tabular}{|c|c|c|c|c|c|}
\hline PHJ-PSCs structure & $V_{\mathrm{oc}}(\mathrm{V})$ & $J_{\mathrm{sc}}\left(\mathrm{mA} \mathrm{cm}^{-2}\right)$ & $F F(\%)$ & PCE (\%) & Ref \\
\hline ITO/PEDOT:PSS/CH $\mathrm{NH}_{3} \mathrm{PbI}_{3}(210 \mathrm{~nm}) / \mathrm{PCBM}(10 \mathrm{~nm}) / \mathrm{Al}$ & 0.87 & 13.7 & 62 & $7.5(7.5)$ & {$[36$} \\
\hline ITO/PEDOT:PSS/CH${ }_{3} \mathrm{NH}_{3} \mathrm{PbI}_{3}(210 \mathrm{~nm}) / \mathrm{PCBM}(30 \mathrm{~nm}) / \mathrm{Al}$ & 0.99 & 14.2 & 66 & $9.3(9.5)$ & \\
\hline ITO/PEDOT:PSS/CH $\mathrm{NH}_{3} \mathrm{PbI}_{3}(210 \mathrm{~nm}) / \mathrm{PCBM}(50 \mathrm{~nm}) / \mathrm{Al}$ & 0.89 & 13.3 & 68 & $8.0(8.6)$ & \\
\hline ITO/PEDOT:PSS/CH${ }_{3} \mathrm{NH}_{3} \mathrm{PbI}_{3}(210 \mathrm{~nm}) / \mathrm{PCBM}(90 \mathrm{~nm}) / \mathrm{Al}$ & 0.91 & 10.5 & 64 & $6.2(7.5)$ & \\
\hline ITO/PEDOT:PSS/CH${ }_{3} \mathrm{NH}_{3} \mathrm{PbI}_{3}(290 \mathrm{~nm}) / \mathrm{PCBM}(30 \mathrm{~nm}) / \mathrm{Al}$ & 0.99 & 20.0 & 63 & $12.6(13.5)$ & \\
\hline PHJ-PSCs without $\mathrm{Au} @ \mathrm{SiO}_{2}{ }^{\text {a) }}$ & 0.99 & 18.3 & 60 & $10.9(13.5)$ & {$[42$} \\
\hline PHJ-PSCs with 0.032 pM Au@SiO ${ }_{2}$ & 0.95 & 18.9 & 61 & $11.2(12.8)$ & \\
\hline PHJ-PSCs with 0.047 pM Au@SiO ${ }_{2}$ & 1.04 & 20.7 & 72 & $15.6(17.6)$ & \\
\hline PHJ-PSCs with 0.095 pM Au@SiO ${ }_{2}$ & 1.01 & 20.3 & 70 & $14.5(16.0)$ & \\
\hline $\mathrm{ITO} / \mathrm{CH}_{3} \mathrm{NH}_{3} \mathrm{PbI}_{3}(290 \mathrm{~nm}) / \mathrm{PCBM}(30 \mathrm{~nm}) / \mathrm{Al}$ & 1.00 & 18.3 & 51 & $9.3(11.3)$ & {$[38$} \\
\hline
\end{tabular}

a) The structure of PHJ-PSCs is ITO/PEDOT:PSS/CH $\mathrm{NH}_{3} \mathrm{PbI}_{3}(290 \mathrm{~nm}) / \mathrm{PCBM} / \mathrm{Al}$, and $\mathrm{Au} @ \mathrm{SiO}_{2}$ nanorods were inserted at the interface between the PEDOT:PSS layer and $\mathrm{CH}_{3} \mathrm{NH}_{3} \mathrm{PbI}_{3}$ layer. 
eliminate the charge recombination and exciton quenching loss at the metal surface. Meanwhile, metal nanorods are normally better than spherical-shaped metal NPs in enhancing local electromagnetic field and accordingly exhibit superior photovoltaic performance [66].

Based on PHJ-PSCs with a simple structure of ITO/PEDOT:PSS $/ \mathrm{CH}_{3} \mathrm{NH}_{3} \mathrm{PbI}_{3} / \mathrm{PCBM} / \mathrm{Al}$, silica-coated gold $\left(\mathrm{Au} @ \mathrm{SiO}_{2}\right)$ core-shell nanorods as the modification layer was inserted at the interface between the HTL PEDOT:PSS and the active layer $\mathrm{CH}_{3} \mathrm{NH}_{3} \mathrm{PbI}_{3}$ via low temperature, solution process for hopefully improving the photovoltaic performance [42]. The Au nanorods were embedded in dielectric matrix $\mathrm{SiO}_{2}$ forming a core-shell structure. The average diameter and length of $\mathrm{Au}$ nanorod were about $16.8 \mathrm{~nm}$ and $34.7 \mathrm{~nm}$, respectively, and the thickness of $\mathrm{SiO}_{2}$ shell was $9.5 \mathrm{~nm}$. The absorption spectrum of $\mathrm{Au} @ \mathrm{SiO}_{2}$ nanorods indicated that $\mathrm{Au} @ \mathrm{SiO}_{2}$ nanorods exhibited a transverse localized SP resonance peak at about $522 \mathrm{~nm}$ and a longitudinal localized SP resonant peak at about $700 \mathrm{~nm}$. The morphology and XRD patterns of $\mathrm{CH}_{3} \mathrm{NH}_{3} \mathrm{PbI}_{3}$ thin films on PEDOT:PSS layer with or without $\mathrm{Au} @ \mathrm{SiO}_{2}$ nanorods were very similar, suggesting that both $\mathrm{CH}_{3} \mathrm{NH}_{3} \mathrm{PbI}_{3}$ thin films were homogeneous and well crystalline [42].

The performance parameters of PHJ-PSCs with $\mathrm{Au} @ \mathrm{SiO}_{2}$ nanorods were improved dramatically, and they were dependent on the concentration of $\mathrm{Au} @ \mathrm{SiO}_{2}$ nanorods (Table 2). Based on the optimized concentration at $0.047 \mathrm{pmol} \mathrm{L}^{-1}$, the average $V_{\mathrm{oc}}, J_{\mathrm{sc}}$, and $F F$ were improved from $0.99 \mathrm{~V}, 18.3 \mathrm{~mA} \mathrm{~cm}^{-2}$ and $60 \%$ to 1.04 $\mathrm{V}, 20.7 \mathrm{~mA} \mathrm{~cm}^{-2}$, and $72 \%$, respectively, resulting in the obvious improvement of average PCEs from $10.9 \%$ to $15.6 \%$ without obvious hysteresis under different scanning directions and speeds. Especially, the PCEs of champion PHJ-PSCs up to $17.6 \%$ could be achieved [42]. The similar improvement trend was also reported by Snaith's group that incorporating spherical-shaped metal NPs into $\mathrm{Al}_{2} \mathrm{O}_{3}$ matrix leaded to the enhancement of average PCEs from $8.5 \%$ to $9.5 \%$ [68].

The incident photon to current conversion efficiency

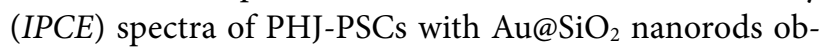
viously indicated that there was significant enhancement (Fig. 7a). The absorption spectra of $\mathrm{CH}_{3} \mathrm{NH}_{3} \mathrm{PbI}_{3}$ thin films with $\mathrm{Au} @ \mathrm{SiO}_{2}$ nanorods exhibited higher absorption over a broad wavelength range than that without $\mathrm{Au} @ \mathrm{SiO}_{2}$ nanorods (Fig. $7 \mathrm{~b}$ ). The calculated wavelength-dependent enhancement factors, i.e., IPCE ( $\triangle I P C E)$ and absorption $(\triangle A b s)$, were roughly similar to each other in shape with the intensities over the whole wavelength range (Fig. $7 \mathrm{c}$ ). The increase in $J_{\mathrm{sc}}$, on the one hand, came from the improvement of absorption with $\mathrm{Au} @ \mathrm{SiO}_{2}$ nanorods. The simulation of electric field distribution clearly suggested
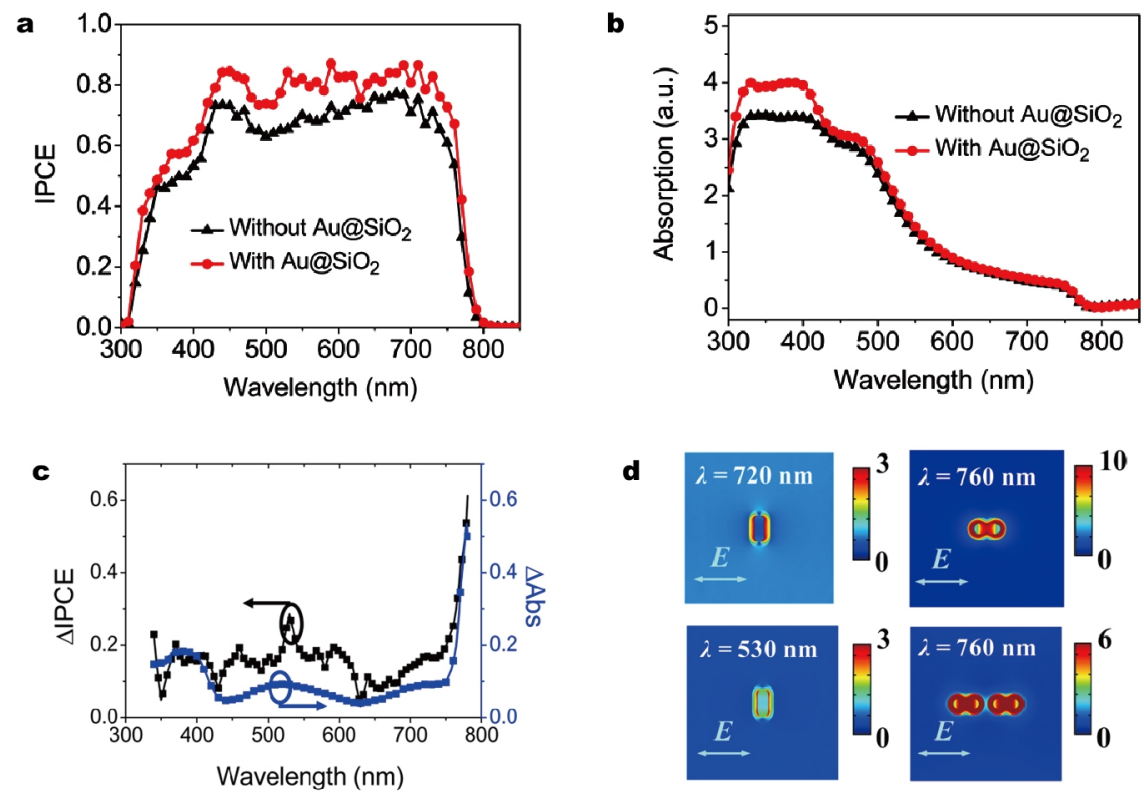

Figure 7 (a, b) IPCE spectra of PHJ-PSCs and absorption spectra of $\mathrm{CH}_{3} \mathrm{NH}_{3} \mathrm{PbI}_{3}$ thin films with and without Au@SiO ${ }_{2}$ nanorods, respectively. (c) Calculated wavelength-dependent enhancement factors of the IPCE $(\triangle I P C E)$ and absorption $(\triangle A b s)$. (d) Calculated electric field distributions for Au@SiO ${ }_{2}$ nanorods (single or pair) at the denoted wavelengths and polarization. Reprinted with permission from [42], Copyright 2016, American Chemical Society. 
that the electric field around $\mathrm{Au} @ \mathrm{SiO}_{2}$ nanorods could be indeed significantly enhanced by the excitation of SP resonance (Fig. 7d), which coupled light into the perovskite thin film and improved the absorption, resulting in the improvement in $J_{\mathrm{sc}}$ and PCEs. On the other hand, the insertion of $\mathrm{Au} @ \mathrm{SiO}_{2}$ nanorods could improve the electrical properties in PHJ-PSCs, resulting in the improvement in IPCE as well. The excitation of the localized SP resonance would benefit the dissociation and restrain the recombination of charge carriers, which contributes to the enhancement in $F F$ and $J_{\text {sc }}$, resulting in the improved PCEs.

\section{HTL-free planar heterojunction PSCs}

Although the structure of PHJ-PSCs is very simple (Fig. 6), researchers are still looking for more simple structure to fabricate efficient PHJ-PSCs, for example, HTL-free PHJ-PSCs or ETL-free PHJ-PSCs [38,69], which can further simplify the fabrication of large-area PSCs with large-scale printing techniques.

As discussed above, the PEDOT:PSS acting as the HTL was widely employed in low-temperature, solution-processed PHJ-PSCs, but the PEDOT:PSS showed obvious drawbacks with strong acidity and intrinsic hygroscopic property which definitely influenced the performance of PHJ-PSCs. The ITO electrode would be eroded as well resulted from extreme acidity characteristic, and the water-absorbing would contribute to the rapidly degradation of active layer leading to the quickly damping for overall PSC devices. Thus, the HTL-free PHJ-PSCs with a structure of ITO/ $\mathrm{CH}_{3} \mathrm{NH}_{3} \mathrm{PbI}_{3} / \mathrm{PCBM} / \mathrm{Al}$ were explored [38]. The $\mathrm{CH}_{3} \mathrm{NH}_{3} \mathrm{PbI}_{3}$ thin films deposited on the ITO and ITO/PEDOT:PSS substrates showed the similar properties (Fig. 8), e.g., crystallization, absorption, and morphology. The results suggested that smooth, continuous and uniform $\mathrm{CH}_{3} \mathrm{NH}_{3} \mathrm{PbI}_{3}$ thin films with high crystallinity could be obtained on the ITO substrate directly for fabricating PHJ-PSCs devices. The performance parameters of HTL-free PHJ-PSC devices indicated that the average $V_{\text {oc }}$ and PCE could reach to $1.0 \mathrm{~V}$ and $9.3 \%$, respectively (the best $P C E$ was up to $11.3 \%$ ), which showed a significant enhancement as compared with the first work reported by Etgar et al. [70] that HTL-free PHJ-PSCs with a structure of $\mathrm{CH}_{3} \mathrm{NH}_{3} \mathrm{PbI}_{3} / \mathrm{TiO}_{2}$ yielded a $P C E$ of $5.5 \%$. These performance parameters were comparable to that of PHJ-PSCs
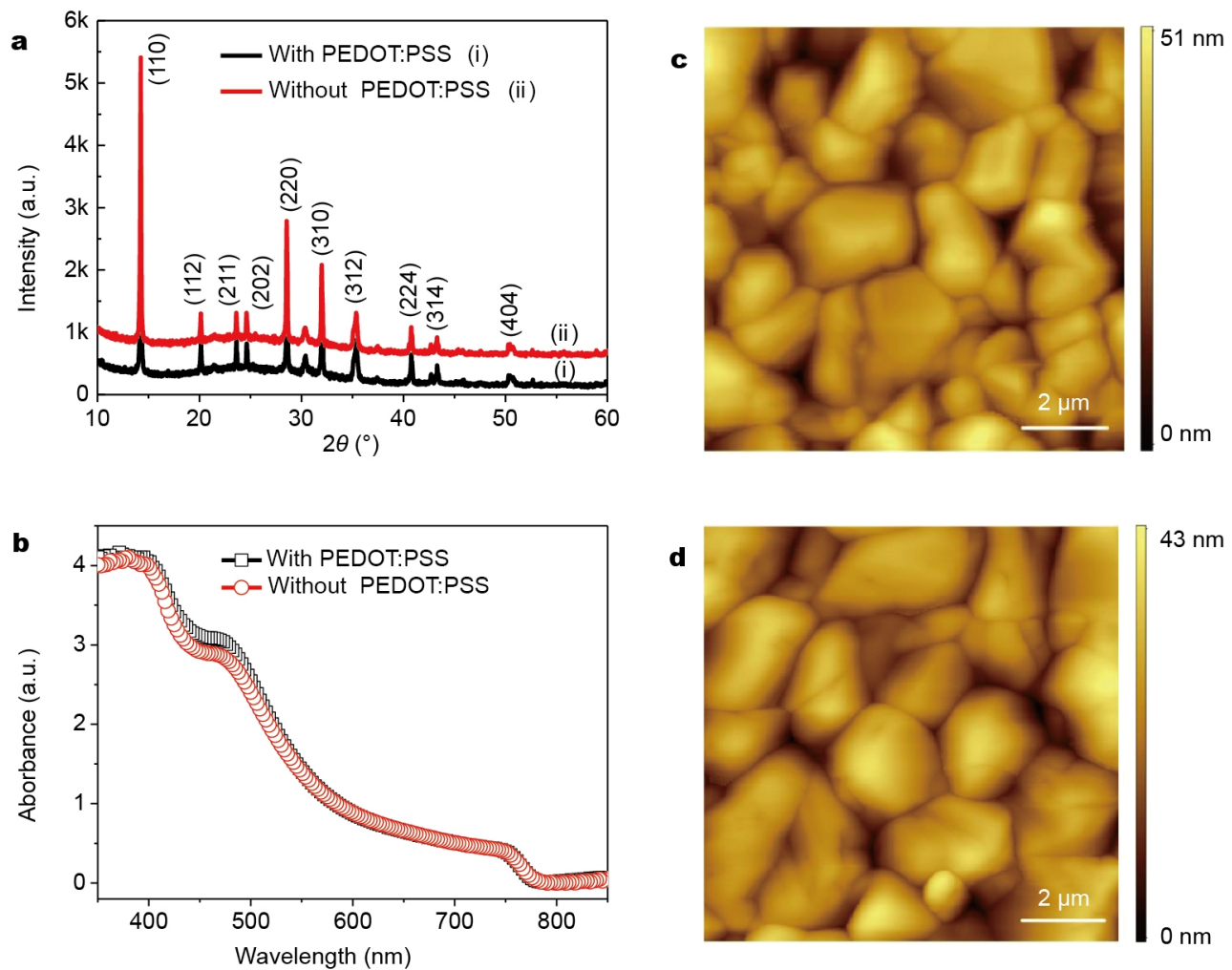

Figure 8 (a) XRD and (b) absorbance patterns of $\mathrm{CH}_{3} \mathrm{NH}_{3} \mathrm{PbI}_{3}$ thin films deposited on the ITO and PEDOT:PSS coated ITO substrates, respectively. (c, d) Morphology of $\mathrm{CH}_{3} \mathrm{NH}_{3} \mathrm{PbI}_{3}$ thin films deposited on the ITO and PEDOT:PSS coated ITO substrates, respectively. Reprinted with permission from [38], Copyright 2015, Elsevier. 
with a PEDOT:PSS layer (Table 2). Especially, the $J-V$ curves of HTL-free PHJ-PSCs are very similar under different scanning speeds and directions, suggesting that almost no hysteresis was observed in HTL-free PHJ-PSCs. It resulted from the low trap states of HTL-free PHJ-PSCs and they could be gradually filled by the charge carriers under different scanning speeds and directions.

In addition, the HTL-free PHJ-PSCs showed a much better stability than the PHJ-PSCs with a PEDOT:PSS layer stored in a nitrogen-filled glove box or in ambient air (humidity $~ 50 \%$ ) without any encapsulation at room temperature. The performance degradation of PHJ-PSC devices could probably be attributed to the decomposition of perovskite materials or interface degradation induced by the moisture. The hydrophilic PEDOT:PSS layer would accelerate the degradation of PHJ-PSCs. Meanwhile, the strong acidity of the PEDOT:PSS would corrode the electrode ITO as well, resulting in the performance degradation. Thus it is a promising alternative to fabricate HTL-free PHJ-PSCs for considering the encouraging PCEs and stability, as well as the simpler structure and manufacture process.

\section{Planar heterojunction PSCs with interface layer $\mathrm{TiO}_{2} \mathrm{NPs}$} The PHJ-PSCs with a structure of ITO/PEDOT:PSS/

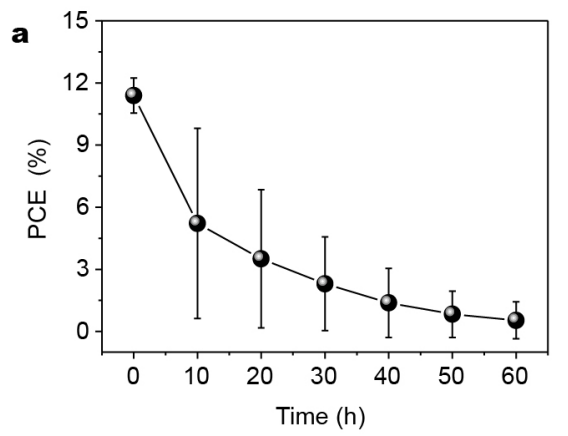

$\mathrm{CH}_{3} \mathrm{NH}_{3} \mathrm{PbI}_{3} / \mathrm{PCBM} / \mathrm{Al}$ is not very stable in air, and the PCEs showed an obvious degradation (Fig. 9a). The results showed that the deviation of PCEs was much larger at the exposure time from 10 to $30 \mathrm{~min}$ than that of the original performance deviation. More obviously, the average PCEs dramatically degraded from about $11.4 \%$ to $0.5 \%$ after only $1 \mathrm{~h}$ exposure in air, suggesting that PHJ-PSCs almost did not work any more.

Normally perovskite materials are sensitive to the moisture and would degrade in air. It is very meaningful to check how $\mathrm{CH}_{3} \mathrm{NH}_{3} \mathrm{PbI}_{3}$ thin film itself influences the performance of PHJ-PSCs as they are exposed to air (relative humidity, $\mathrm{RH} \sim 45 \%$ ). Thus the $\mathrm{CH}_{3} \mathrm{NH}_{3} \mathrm{PbI}_{3}$ thin films on ITO/PEDOT:PSS substrates were prepared and exposed to air for a specified time. The XRD results proved that some degradation happened as the $\mathrm{CH}_{3} \mathrm{NH}_{3} \mathrm{PbI}_{3}$ thin films exposed to air $(R H \sim 45 \%)$ for $200 \mathrm{~h}$ due to the emergence of the diffraction peak coming from $\mathrm{PbI}_{2}$ crystals [41]. These $\mathrm{CH}_{3} \mathrm{NH}_{3} \mathrm{PbI}_{3}$ thin films exposed to air for a specified time were used to fabricate PHJ-PSCs with a structure of ITO/PEDOT:PSS $/ \mathrm{CH}_{3} \mathrm{NH}_{3} \mathrm{PbI}_{3} / \mathrm{PCBM} / \mathrm{Al}$. It was very interesting that all the PHJ-PSC devices worked well, and the PCEs were over $10 \%$ (Fig. 9b). Even for the $\mathrm{CH}_{3} \mathrm{NH}_{3} \mathrm{PbI}_{3}$ thin film exposed to air for $200 \mathrm{~h}$, the PCE still could reach

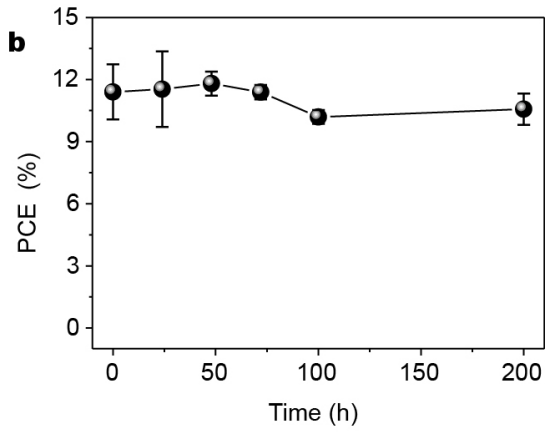

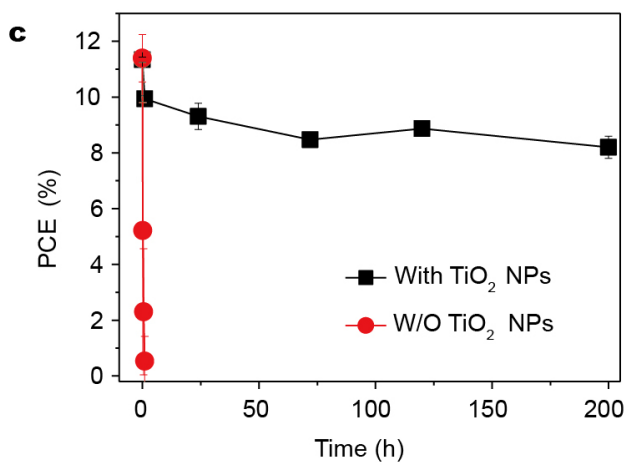

Figure 9 (a) The average degradation behavior of PHJ-PSCs with a structure of ITO/PEDOT:PSS/ $\mathrm{CH}_{3} \mathrm{NH}_{3} \mathrm{PbI}_{3} / \mathrm{PCBM} / \mathrm{Al}$ as the exposure time in air (RH $45 \%$ ). (b) The average degradation performance of PHJ-PSCs with ITO/PEDOT:PSS $/ \mathrm{CH}_{3} \mathrm{NH}_{3} \mathrm{PbI}_{3}$ thin films exposed to air during $200 \mathrm{~h}$. (c) The degradation trend of PCEs for PHJ-PSCs with and without $\mathrm{TiO}_{2} \mathrm{NPs}$ interface layer between the PCBM layer and the electrode Al. Reprinted with permission from [30], Copyright 2016, Elsevier. 
to $11.3 \%$ with $J_{\mathrm{sc}}$ of $18.2 \mathrm{~mA} \mathrm{~cm}{ }^{-2}, V_{\mathrm{oc}}$ of $0.97 \mathrm{~V}$ and $F F$ of $64 \%$. The results suggested that the performance degradation of $\mathrm{PHJ}$-PSCs based on the $\mathrm{CH}_{3} \mathrm{NH}_{3} \mathrm{PbI}_{3}$ thin films exposed to air was not obvious (Fig. 9b), which was totally different to the quick degradation of PHJ-PSC devices exposed to air (Fig. 9a). It is probable that the perovskite thin films with a little excess $\mathrm{PbI}_{2}$ as the active layer did not obviously influence the performance of PHJ-PSCs and the PCEs could still be over $10 \%$. The experiment results indicated that the degradation of $\mathrm{CH}_{3} \mathrm{NH}_{3} \mathrm{PbI}_{3}$ thin film itself was not the main reason contributing to the performance degradation of PHJ-PSC devices.

Generally speaking, the degradation of PHJ-OSCs and PHJ-PSCs can be classified into interface degradation and intrinsic function-layer (active layer, HTL, ETL) degradation. The interface degradation normally leads to a quick process at the initial stage. The in-situ experiments observed with an optical microscope could follow the degradation process of PHJ-PSCs exposed to air at the initial stage (Fig. 10 and the video in Ref [41]). The morphology indicated that there were lots of bubbles formed quickly, as indicated by the red arrows, and the bubble size became larger and larger with the exposure time extension. Meanwhile, more and more bubbles formed as well (Fig. 10b). The cross-sectional SEM image confirmed the formation of the Al electrode bubbles which were hollows (Fig. 10c). The formation of Al bubbles should be closely related to the $\mathrm{CH}_{3} \mathrm{NH}_{3} \mathrm{PbI}_{3}$ material and its exposure to air. The $\mathrm{CH}_{3} \mathrm{NH}_{3} \mathrm{PbI}_{3}$ material exposed to air would react with the water and result in the production of gas $[23,40]$, which accelerated the formation of Al bubbles. No bubbles could be observed if without depositing the Al electrode. The results obviously suggested that the interface issue between the

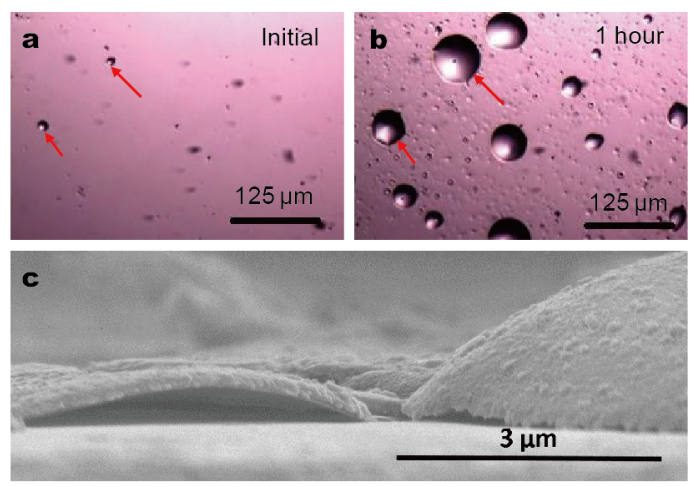

Figure 10 The evolution of Al electrode bubbles formed on the surface of perovskite layer at the initial stage (a) and after $1 \mathrm{~h}$ exposure to air (b). (c) Cross-section SEM morphology image of the Al electrode bubbles. Reprinted with permission from [30], Copyright 2014, Elsevier.
$\mathrm{CH}_{3} \mathrm{NH}_{3} \mathrm{PbI}_{3} / \mathrm{PCBM}$ (or $\mathrm{CH}_{3} \mathrm{NH}_{3} \mathrm{PbI}_{3}$ ) and the $\mathrm{Al}$ cathode was the main reason resulting in the performance degradation of PHJ-PSCs.

As discussed in previous section, $\mathrm{TiO}_{2} \mathrm{NPs}$ as the interface modification layer can dramatically improve the stability of OSCs $[29,30]$. Thus, the $\mathrm{TiO}_{2} \mathrm{NPs}$ were also introduced into the interface between the PCBM layer and the $\mathrm{Al}$ electrode for hopefully enhancing the stability of $\mathrm{PHJ}$ PSCs. The oxygen deficiencies-rich $\mathrm{TiO}_{2} \mathrm{NPs}$ could prevent the penetration of oxygen and humidity into the electronically active layer and would lead to the enhancement of stability of PHJ-PSCs. The results in Fig. 9c indicated that the stability of PHJ-PSCs with a $\mathrm{TiO}_{2}$ NPs layer inserted between the PCBM layer and the $\mathrm{Al}$ electrode was dramatically improved as compared with PHJ-PSCs without a $\mathrm{TiO}_{2}$ NPs layer. Even exposure in air for $200 \mathrm{~h}$, the PCEs still remained over $75 \%$ of its original value, of which the PCEs just degraded from about $11 \%$ to about $9 \%$. While the PHJ-PSCs without a $\mathrm{TiO}_{2}$ NPs layer degraded very quickly and almost died completely as exposure to air in $1 \mathrm{~h}$. The insertion of $\mathrm{TiO}_{2} \mathrm{NPs}$ as the interface modification layer greatly improved the stability of PHJ-PSCs.

\section{CONCLUSIONS}

The research progress on the interface modification of OSCs and PSCs in our group was summarized.

Combining molecular template growth and glancing angle deposition technique, high-quality organic semiconductor thin films with controllable morphology and molecular orientation were fabricated, which were helpful to produce highly efficient small molecular OSCs. (2) The $\mathrm{TiO}_{2}$ NPs synthesized by newly developed low-temperature, solution-processed method were used as the ETL to fabricate efficient and stable polymer OSCs with conventional forward structure and inverted structure. (3) The GO was used to replace the PEDOT:PSS as the HTL for obtaining efficient and stable polymer OSCs, but the performance was strongly dependent on the thickness of GO. (4) Based on a simple structure of ITO/PEDOT:PSS/ $\mathrm{CH}_{3} \mathrm{NH}_{3} \mathrm{PbI}_{3} / \mathrm{PCBM} / \mathrm{Al}$, highly efficient PHJ-PSCs were fabricated. The PCE up to $17.6 \%$ was obtained for the HTL PEDOT:PSS modified using $\mathrm{Au} @ \mathrm{SiO}_{2}$ nanorods,. Furthermore, a more simple and stable HTL-free PHJ-PSCs could be fabricated with an average $P C E$ of $9.3 \%$. In addition, the insertion of $\mathrm{TiO}_{2}$ NPs as the interface modification layer between the PCBM layer and the $\mathrm{Al}$ electrode could prevent the formation of Al bubbles and greatly improved the stability of PHJ-PSCs. 
It is well recognized that the interface plays a very important role in determining the photovoltaic performance and stability for both OSCs and PSCs. For a good interface material, on one hand, it should have appropriate energy levels, which should match with the energy levels of adjacent layers. Thus it is advantageous for the extraction of electrons or holes from the active layer, as well as the improvement of the $V_{\text {oc }}$. On the other hand, the interface layer should be helpful to the formation of high-quality active layer, for example, molecular template layer, which would improve the separation of excitons and transport of carriers, resulting in the enhancement of photovoltaic parameters. In addition, some special interface layers can improve the stability of OSCs or PSCs because they play as the blocking layer for water or oxygen penetration which would stabilize the device performance. Hence, the interface layer should at least play as one of functions discussed above, and multifunctional interface layer is preferable to be chosen.

In order to fabricate large-area, efficient and stable OSCs and PSCs with low cost and high output, the interface materials with suitable energy level and good stability should be developed. Meanwhile, the solution processable interface materials with good thin-film formation property and thickness-independence are eager to be developed for matching with large-scale, low cost, high-output printing techniques, especially matching with R2R printing techniques. Thus, these interface materials would accelerate the development of OSCs and PSCs, as well as their potential commercialization.

Received 9 June 2016; accepted 28 June 2016; published online 10 August 2016

1 Birkmire RW, Eser E. Polycrystalline thin film solar cells: present status and future potential. Annu Rev Mater Sci, 1997, 27: 625-653

2 Ameri T, Dennler G, Lungenschmied C, et al. Organic tandem solar cells: a review. Energy Environ Sci, 2009, 2: 347-363

3 Song C, Wang X, Song J, et al. Boron doped nanocrystalline silicon film characterization for solar cell application. Sci China Mater, 2015, 58: 704-708

4 Søndergaard R, Hösel M, Angmo D, et al. Roll-to-roll fabrication of polymer solar cells. Mater Today, 2012, 15: 36-49

5 Yang J, Vak D, Clark N, et al. Organic photovoltaic modules fabricated by an industrial gravure printing proofer. Solar Energy Mater Solar Cells, 2013, 109: 47-55

$6 \mathrm{Hu} \mathrm{Q}, \mathrm{Wu} \mathrm{H}$, Sun J, et al. Large-area perovskite nanowire arrays fabricated by large-scale roll-to-roll micro-gravure printing and doctor blading. Nanoscale, 2016, 8: 5350-5357

7 Hwang K, Jung YS, Heo YJ, et al. Toward large scale roll-to-roll production of fully printed perovskite solar cells. Adv Mater, 2015, 27: $1241-1247$

8 Kim JY, Lee K, Coates NE, et al. Efficient tandem polymer solar cells fabricated by all-solution processing. Science, 2007, 317: 222-225

9 Green MA, Emery K, Hishikawa Y, et al. Solar cell efficiency tables
(Version 45). Prog Photovolt-Res Appl, 2015, 23: 1-9

10 You J, Dou L, Yoshimura K, et al. A polymer tandem solar cell with 10.6\% power conversion efficiency. Nat Commun, 2013, 4: 1446

11 Zhao J, Li Y, Yang G, et al. Efficient organic solar cells processed from hydrocarbon solvents. Nat Energy, 2016, 1: 15027

12 Yang WS, Noh JH, Jeon NJ, et al. High-performance photovoltaic perovskite layers fabricated through intramolecular exchange. Science, 2015, 348: 1234-1237

13 Bi D, Tress W, Dar MI, et al. Efficient luminescent solar cells based on tailored mixed-cation perovskites. Sci Adv, 2016, 2: e1501170

14 http://www.nrel.gov/ncpv/images/efficiency_chart.jpg (June 2016)

15 Turak A. Interfacial degradation in organic optoelectronics. RSC Adv, 2013, 3: 6188-6225

16 Jørgensen M, Norrman K, Gevorgyan SA, et al. Stability of polymer solar cells. Adv Mater, 2012, 24: 580-612

17 Noh JH, Im SH, Heo JH, et al. Chemical management for colorful, efficient, and stable inorganic-organic hybrid nanostructured solar cells. Nano Lett, 2013, 13: 1764-1769

18 Steim R, Kogler FR, Brabec CJ. Interface materials for organic solar cells. J Mater Chem, 2010, 20: 2499-2512

19 Chen LM, Xu Z, Hong Z, et al. Interface investigation and engineering-achieving high performance polymer photovoltaic devices. J Mater Chem, 2010, 20: 2575-2598

20 He Z, Zhong C, Su S, et al. Enhanced power-conversion efficiency in polymer solar cells using an inverted device structure. Nat Photon, 2012, 6: 593-597

21 Yip HL, Jen AKY. Recent advances in solution-processed interfacial materials for efficient and stable polymer solar cells. Energy Environ Sci, 2012, 5: 5994-6011

22 Eperon GE, Burlakov VM, Docampo P, et al. Morphological control for high performance, solution-processed planar heterojunction perovskite solar cells. Adv Funct Mater, 2014, 24: 151-157

23 Niu G, Li W, Meng F, et al. Study on the stability of $\mathrm{CH}_{3} \mathrm{NH}_{3} \mathrm{PbI}_{3}$ films and the effect of post-modification by aluminum oxide in allsolid-state hybrid solar cells. J Mater Chem A, 2014, 2: 705-710

24 Dong X, Fang X, Lv M, et al. Improvement of the humidity stability of organic-inorganic perovskite solar cells using ultrathin $\mathrm{Al}_{2} \mathrm{O}_{3}$ layers prepared by atomic layer deposition. J Mater Chem A, 2015, 3: 5360-5367

25 Yang J, Yan D. Weak epitaxy growth of organic semiconductor thin films. Chem Soc Rev, 2009, 38: 2634-2645

26 Wu H, Yang J, Cao S, et al. Ordered organic nanostructures fabricated from anodic alumina oxide templates for organic bulk-heterojunction photovoltaics. Macromol Chem Phys, 2014, 215: 584-596

27 Yang J, Yan D, Jones TS. Molecular template growth and its applications in organic electronics and optoelectronics. Chem Rev, 2015, 115: 5570-5603

28 Yang B, Duan H, Zhou C, et al. Ordered nanocolumn-array organic semiconductor thin films with controllable molecular orientation. Appl Surface Sci, 2013, 286: 104-108

29 Xiong J, Yang B, Zhou C, et al. Enhanced efficiency and stability of polymer solar cells with $\mathrm{TiO}_{2}$ nanoparticles buffer layer. Org Electron, 2014, 15: 835-843

30 Xiong J, Yang J, Yang B, et al. Efficient and stable inverted polymer solar cells using $\mathrm{TiO}_{2}$ nanoparticles and analysized by Mott-Schottky capacitance. Org Electron, 2014, 15: 1745-1752

31 Fan L, Cui R, Guo X, et al. A new two-dimensional donor/acceptor copolymer based on 4,8-bis $(2$-ethylhexylthiophene)thieno[2,3-f]benzofuran for high-performance polymer solar cells. J Mater Chem C, 2014, 2: 5651-5659

$32 \mathrm{Hu}$ X, Xiong J, Tang Y, et al. Interface modification of polymer 
solar cells using graphene oxide and $\mathrm{TiO}_{2}$ NPs. Phys Status Solidi A, 2015, 212: 585-590

33 Xiong J, Yang B, Yuan J, et al. Efficient organic photovoltaics using solution-processed, annealing-free $\mathrm{TiO}_{2}$ nanocrystalline particles as an interface modification layer. Org Electron, 2015, 17: 253-261

34 Duan $\mathrm{H}$, Yang J, Fu L, et al. Interface modification of organic photovoltaics by combining molybdenum oxide $\left(\mathrm{MoO}_{x}\right)$ and molecular template layer. Thin Solid Films, 2015, 574: 146-151

35 Yang J, Yim S, Jones TS. Molecular-orientation-induced rapid roughening and morphology transition in organic semiconductor thin-film growth. Sci Rep, 2015, 5: 9441

36 Xiong J, Yang $\mathrm{B}, \mathrm{Wu} \mathrm{R}$, et al. Efficient and non-hysteresis $\mathrm{CH}_{3} \mathrm{NH}_{3} \mathrm{PbI}_{3} / \mathrm{PCBM}$ planar heterojunction solar cells. Org Electron, 2015, 24: 106-112

37 Wu R, Yang B, Xiong J, et al. Dependence of device performance on the thickness of compact $\mathrm{TiO}_{2}$ layer in perovskite/ $/ \mathrm{TiO}_{2}$ planar heterojunction solar cells. J Renew Sustain Energy, 2015, 7: 043105

38 Wu R, Yang J, Xiong J, et al. Efficient electron-blocking layer-free planar heterojunction perovskite solar cells with a high open-circuit voltage. Org Electron, 2015, 26: 265-272

$39 \mathrm{Li} \mathrm{Y,} \mathrm{Xu} \mathrm{X,} \mathrm{Wang} \mathrm{C,} \mathrm{et} \mathrm{al.} \mathrm{Investigation} \mathrm{on} \mathrm{thermal} \mathrm{evaporated}$ $\mathrm{CH}_{3} \mathrm{NH}_{3} \mathrm{PbI}_{3}$ thin films. AIP Adv, 2015, 5: 097111

40 Li Y, Xu X, Wang C, et al. Degradation by exposure of coevaporated $\mathrm{CH}_{3} \mathrm{NH}_{3} \mathrm{PbI}_{3}$ thin films. J Phys Chem C, 2015, 119: 23996-24002

41 Xiong J, Yang B, Cao C, et al. Interface degradation of perovskite solar cells and its modification using an annealing-free $\mathrm{TiO}_{2} \mathrm{NPs}$ layer. Org Electron, 2016, 30: 30-35

42 Wu R, Yang B, Zhang C, et al. Prominent efficiency enhancement in perovskite solar cells employing silica-coated gold nanorods. J Phys Chem C, 2016, 120: 6996-7004

43 Cao C, Zhang C, Yang J, et al. Iodine and chlorine element evolution in $\mathrm{CH}_{3} \mathrm{NH}_{3} \mathrm{PbI}_{3-x} \mathrm{Cl}_{x}$ thin films for highly efficient planar heterojunction perovskite solar cells. Chem Mater, 2016, 28: 2742-2749

44 Angmo D, Larsen-Olsen TT, Jørgensen M, et al. Roll-to-roll inkjet printing and photonic sintering of electrodes for ITO free polymer solar cell modules and facile product integration. Adv Energy Mater, 2012, 3: 172-175

45 Välimäki M, Apilo P, Po R, et al. R2R-printed inverted OPV modules - towards arbitrary patterned designs. Nanoscale, 2015, 7: 9570-9580

46 Yang PC, Sun JY, Ma SY, et al. Interface modification of a highly air-stable polymer solar cell. Solar Energy Mater Solar Cells, 2012, 98: $351-356$

47 Li YQ, Wang QK, Ou QD, et al. Interface energetics and engineering of organic heterostructures in organic photovoltaic cells. Sci China Chem, 2016, 59: 422-435

48 Ye L, Fan B, Zhang S, et al. Perovskite-polymer hybrid solar cells with near-infrared external quantum efficiency over $40 \%$. Sci China Mater, 2015, 58: 953-960

49 Chauhan KV, Sullivan P, Yang JL, et al. Efficient organic photovoltaic cells through structural modification of chloroaluminum phthalocyanine/fullerene heterojunctions. J Phys Chem C, 2010, 114: $3304-3308$

50 Kim JY, Kim SH, Lee HH, et al. New architecture for high-efficiency polymer photovoltaic cells using solution-based titanium oxide as an optical spacer. Adv Mater, 2006, 18: 572-576

51 Yoon SJ, Park JH, Lee HK, et al. Low vacuum process for polymer solar cells: effect of $\mathrm{TiO}_{x}$ interlayer. Appl Phys Lett, 2008, 92: 143504

52 Lee K, Kim JY, Park SH, et al. Air-stable polymer electronic devices.
Adv Mater, 2007, 19: 2445-2449

53 Wang DH, Im SH, Lee HK, et al. Enhanced high-temperature longterm stability of polymer solar cells with a thermally stable $\mathrm{TiO}_{x}$ interlayer. J Phys Chem C, 2009, 113: 17268-17273

54 Park MH, Li JH, Kumar A, et al. Doping of the metal oxide nanostructure and its influence in organic electronics. Adv Funct Mater, 2009, 19: 1241-1246

55 Salim T, Yin Z, Sun S, et al. Solution-processed nanocrystalline $\mathrm{TiO}_{2}$ buffer layer used for improving the performance of organic photovoltaics. ACS Appl Mater Interfaces, 2011, 3: 1063-1067

56 Hau SK, Yip HL, Jen AKY. A review on the development of the inverted polymer solar cell architecture. Polymer Rev, 2010, 50: 474-510

57 Cheng P, Zhan X. Stability of organic solar cells: challenges and strategies. Chem Soc Rev, 2016, 45: 2544-2582

58 Kim JB, Kim CS, Kim YS, et al. Oxidation of silver electrodes induces transition from conventional to inverted photovoltaic characteristics in polymer solar cells. Appl Phys Lett, 2009, 95: 183301

59 Wan X, Long G, Huang L, et al. Graphene-a promising material for organic photovoltaic cells. Adv Mater, 2011, 23: 5342-5358

60 Liu J, Xue Y, Gao Y, et al. Hole and electron extraction layers based on graphene oxide derivatives for high-performance bulk heterojunction solar cells. Adv Mater, 2012, 24: 2228-2233

61 Kojima A, Teshima K, Shirai Y, et al. Organometal halide perovskites as visible-light sensitizers for photovoltaic cells. J Am Chem Soc, 2009, 131: 6050-6051

62 Lee MM, Teuscher J, Miyasaka T, et al. Efficient hybrid solar cells based on meso-superstructured organometal halide perovskites. Science, 2012, 338: 643-647

63 Jeon NJ, Noh JH, Kim YC, et al. Solvent engineering for highperformance inorganic-organic hybrid perovskite solar cells. Nat Mater, 2014, 13: 897-903

64 Jeng JY, Chiang YF, Lee $\mathrm{MH}$, et al. $\mathrm{CH}_{3} \mathrm{NH}_{3} \mathrm{PbI}_{3}$ perovskite/fullerene planar-heterojunction hybrid solar cells. Adv Mater, 2013, 25: 3727-3732

65 Wang Q, Shao Y, Dong Q, et al. Large fill-factor bilayer iodine perovskite solar cells fabricated by a low-temperature solution-process. Energy Environ Sci, 2014, 7: 2359-2365

$66 \mathrm{Lu} \mathrm{L}$, Luo Z, Xu T, et al. Cooperative plasmonic effect of Ag and Au nanoparticles on enhancing performance of polymer solar cells. Nano Lett, 2013, 13: 59-64

67 Cui Y, Zhao H, Yang F, et al. Efficiency enhancement in organic solar cells by incorporating silica-coated gold nanorods at the buffer/active interface. J Mater Chem C, 2015, 3: 9859-9868

68 Zhang W, Saliba M, Stranks SD, et al. Enhancement of perovskitebased solar cells employing core-shell metal nanoparticles. Nano Lett, 2013, 13: 4505-4510

69 Ke W, Fang G, Wan J, et al. Efficient hole-blocking layer-free planar halide perovskite thin-film solar cells. Nat Commun, 2015, 6: 6700

70 Etgar L, Gao $\mathrm{P}$, Xue Z, et al. Mesoscopic $\mathrm{CH}_{3} \mathrm{NH}_{3} \mathrm{PbI}_{3} / \mathrm{TiO}_{2}$ heterojunction solar cells. J Am Chem Soc, 2012, 134: 17396-17399

Acknowledgments This work was supported by the Program for New Century Excellent Talents in University (NCET-13-0598), the Hunan Provincial Natural Science Foundation of China (2015JJ1015), and the Project of Innovation-driven Plan in Central South University (2015CXS036). Yang J also thanks the support by State Key Laboratory of Powder Metallurgy, Central South University, Changsha, China.

Author contributions Yang J conceived the study. Wang C and Yang J wrote the manuscript. Both authors discussed the manuscripts structure, arguments and conclusions. 
Conflict of interest The authors declare that they have no conflict of interest.

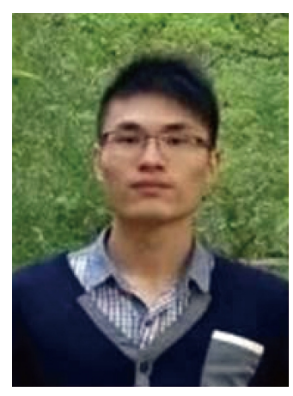

Chunhua Wang received his BSc degree in physics from Xinjiang University in 2015. Now he is a master student in the School of Physics and Electronics at Central South University. His research interests focus on organic solar cells and perovskite solar cells.

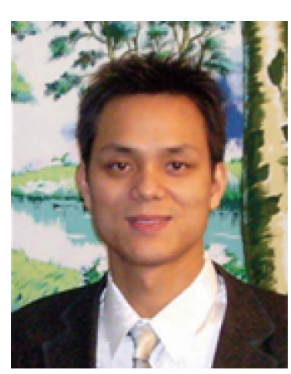

Junliang Yang received his PhD in 2008 from the State Key Laboratory of Polymer Physics and Chemistry at Changchun Institute of Applied Chemistry, Chinese Academy of Sciences. He then worked for two and half years as a postdoctoral research fellow in the Department of Chemistry at the University of Warwick. In April 2011, he moved to Australia and worked as a research fellow in Bio21 Institute at the University of Melbourne, and as a visiting scientist in Flexible Electronics Laboratory at the CSIRO. In March 2012, he was appointed as a full professor in the School of Physics and Electronics at Central South University. His research interests cover the controllable fabrication of highly ordered organic semiconductor thin films, organic electronic and optoelectronic devices, and printed electronics.

\section{有机和钻针矿太阳能电池的界面调控}

王春花 ${ }^{1,2}$, 阳军亮 ${ }^{1,2 *}$

摘要 有机太阳能电池具有柔性、廉价、质轻等优势, 多年来一直受到研究人员的大量关注, 光电转换效率已经达到 $10 \%$ 以上. 特别是最近 几年, 基于有机-无机杂化的钙钛矿太阳能电池发展迅猛, 短短几年内, 光电转换效率突破了 $20 \%$. 界面对有机和钻钛矿太阳能电池的光电转 换效率和稳定性具有举足轻重的作用. 因此, 研究人员聚焦有机和钙钛矿太阳能电池的界面材料、界面修饰、界面工程等开展了深入研 究, 并取得了诸多进展. 本文主要基于作者课题组多年来在有机和钻钛矿太阳能电池的界面研究所取得的初步进展进行了总结, 并对界面 材料的发展方向进行了展望, 期望满足未来基于印刷技术制备高效率、大面积、柔性有机和钻钠矿太阳能电池的需要. 